\title{
Towards Sustainable Resource and Waste Management in Developing Countries: The Role of Commercial and Food Waste in Malaysia
}

\author{
Effie Papargyropoulou ${ }^{\star}$, Rory Padfield, Parveen Fatemeh Rupani and Zuriati Zakaria
}

University Technology Malaysia (UTM), Kuala Lumpur, Malaysia

"Corresponding author: Effie Papargyropoulou, University Technology Malaysia (UTM), Kuala Lumpur, Malaysia, Tel: +60 (0) 322031 ; E-mail: effie@ic.utm.my

Received date: May 16, 2014; Accepted date: July 3, 2014; Published date: July 11, 2014

Copyright: (c) 2014 Papargyropoulou E, et al. This is an open-access article distributed under the terms of the Creative Commons Attribution License, which permits unrestricted use, distribution, and reproduction in any medium, provided the original author and source are credited.

\begin{abstract}
Rising commercial waste generation poses a significant environmental and public health issue, especially in rapidly expanding urban centres in developing countries. A commercial district in Malaysia was selected to explore the challenges and opportunities for minimisation of commercial waste. This research provides empirical data on commercial and food waste generation rates, the problems faced by waste producers, and the priorities for improvement. It is argued that whilst commercial waste offers opportunities for waste minimisation, current challenges related to amenity and public health such as pests, odour and littering, can be addressed by the provision of additional bins, grease traps and improved public areas cleansing. The study concludes that food waste plays a key role in the progression towards a more sustainable waste management system in a developing country such as Malaysia, due to its high generation rates, its contribution to public health and amenity problems, and its high potential for resource recovery.
\end{abstract}

Keywords: Commercial waste; Food waste; Sustainable waste management; Waste generation; Waste minimization; Recycling; Composting; Malaysia

\section{Introduction}

The management of solid wastes continues to be a major challenge in urban areas throughout the world, especially in rapidly growing cities and towns in developing countries (United Nations World Commission on Environment and Development). The Population Reference Bureau [1], estimated the world population to have reached seven billion in 2011, with more than half residing in urban areas (Global Health Observatory 2013). In 2010, 11 billion tons of solid waste were collected worldwide and an even larger but unknown quantity generated [2]. As urbanization continues to take place, the management of solid waste is becoming a significant environmental and public health issue. Various technical, financial, institutional, economic, and social factors are responsible for constraining the development of effective solid waste management systems in developing countries [3]

Even with the increased interest in solid waste management, one waste stream that has not received sufficient attention is that generated from commercial premises [4]. The term commercial waste covers a wide range of commercial businesses and in some cases includes wastes from industrial processes and the construction industry [4-6] In line with the scope of this research, commercial waste in this study was defined as waste from premises used for the purpose of business or trade and it does not include industrial, construction and demolition waste. Strategies to collect, reduce, recycle or otherwise manage commercial waste are often challenging and complex $[4,7]$. However, there is a clear consensus that commercial waste offers attractive opportunities for resource efficiency, waste prevention, reuse and recycling [6-10]. Malaysia is selected as the country of study as it represents a developing country in the rapidly growing region of Southeast Asia that has achieved noteworthy economic growth in the past few decades [11]. During this period, an increase in urbanization has been observed leading to a number of waste management challenges [12]. In turn, the Malaysian governments have developed a number of policies and initiatives to address this issue. The Solid Waste Management and Public Cleansing Bill forms the basis of policy to support the government's targets of 20 per cent recycling, 100 per cent separation at source and closure of all historic, unsanitary disposal sites by 2020 (Ministry of Housing and Local Government Malaysia 2005). Currently, official recycling is estimated to be 3-5 per cent (Ministry of Housing and Local Government Malaysia 2012), although this figure is almost certainly higher due to the contribution of the informal waste management sector [13]. In terms of waste disposal, landfill dominates with 95-97 per cent of the waste collected being disposed in one of the 112 landfills [13]. According to the Ministry of Housing and Local Government Malaysia, the majority of landfills is at full capacity and operates with minimal leachate and landfill gas control. Collection costs make up 83 per cent of the total waste management budget [14] which constrains current efforts for upstream sustainable waste management activities such as minimisation, reuse, recycling, waste treatment and energy from waste [11]. Furthermore, despite efforts by the Ministry of Housing and Local Government Malaysia, public awareness of the environment and waste remains low.

The change in lifestyle and consumption patterns linked to the rapid economic development and population growth in Malaysia has contributed to an increase in waste generation [13]. Waste generation has increased from $0.5 \mathrm{~kg}$ per capita per day in the late $1980 \mathrm{~s}$, to more than $1.3 \mathrm{~kg}$ per capita per day in 2009 [13]. In urban centres, such as Kuala Lumpur and Petaling Jaya, the generation of waste has increased to $1.5-2.5 \mathrm{~kg}$ per capita per day $[13,15,16]$. To date, annual waste generation has reached 11 million tonnes with approximately half comprising of food waste (Japan International Cooperation Agency 2006, Ministry of Housing and Local Government Malaysia 2012) [17]. The increase in the volume of waste is also contributing towards Malaysia's rapidly growing carbon footprint [18]. 
Page 2 of 6

This study provides new empirical data in the less studied field of commercial waste generation in urban areas of the developing world, by presenting a case study in Malaysia. The research explores the generation, challenges and opportunities for sustainable solid waste management of commercial waste. There is a focus on food waste generation, as the food service sector (i.e. restaurants and cafes) is the main waste producer in this study. Policy recommendations for improvement and the relevance of this research are also discussed.

\section{Methodology}

\section{Description of the study area}

A commercial district in urban Malaysia was selected as the study area to investigate the generation of commercial waste, the challenge it poses, and the opportunities it offers for sustainable solid waste management. The commercial district of SS2 Petaling Jaya $\left(3.0833^{\circ} \mathrm{N}\right.$, $101.6500^{\circ} \mathrm{E}$ ) was selected as it represents a typical commercial area in urban Malaysia, comprising a variety of local small to medium commercial businesses (e.g. restaurants, cafes, convenience shops, health and beauty salons, electronics, clothing and furniture retail) and servicing a thriving residential area, in this case the neighborhood of Petaling Jaya. As with most other commercial districts in Malaysia, SS2 faces challenges related to waste management, public cleaning and amenity [19]. These issues are expected to intensify as the surrounding residential area of Petaling Jaya continues to grow.

\section{Research design}

The research design was organized into two main sections. Firstly, a background data assessment on status of the commercial and waste management sectors in Malaysia was conducted. Secondly, a focus group was undertaken with local environmental Non-Governmental Organizations (NGOs), academics and members of the public, to guide the design of a questionnaire (questionnaire template provided in the supplementary material).

Qualitative and quantitative data was collected with the use of an interviewer-administered questionnaire, translated in the three main languages spoken in Malaysia, Bahasa Malaysia (Malay), Mandarin Chinese and English. The team of researchers spoke all three languages which facilitated the research process. All 285 registered commercial businesses in the SS2 area of Petaling Jaya, Malaysia were approached to participate in the survey. In total, 63 questionnaires were completed.

The questionnaire was organized in four thematic sections: background information of the business, waste generation, waste collection, and feedback on the overall waste management service currently provided. The data was further analyzed in quantitative and qualitative ways, in order to add depth to the data analysis and draw fuller picture of the current practices, awareness level, expectations and perceptions related to the management of commercial waste. Statistical analysis was carried out using the PSAW software (version 18). The Analysis of variance (ANOVA) test was applied to determine the statistical significance amongst the results, and assess the correlation between the different variables.

\section{Results and Discussion}

The results are presented and discussed under the four thematic sections described in the methodology section which are i) profile of participating businesses, ii) waste generation, iii) waste collection and iv) feedback on overall waste management service provided.

\section{Profile of participating businesses}

The commercial premises were grouped according to the nature of their business. As illustrated in Table 1, 'Food service' is the largest group including restaurants, cafes and other food service establishments, followed by 'Health and wellbeing' such as pharmacists, gyms, medical doctors, spas, nutrition and healthy eating specialists.

\begin{tabular}{|l|l|l|}
\hline Type of commercial business & Number & $\begin{array}{l}\% \text { of business type in } \\
\text { relation to total sample }\end{array}$ \\
\hline Food service & 24 & $38 \%$ \\
\hline Health and wellbeing & 13 & $21 \%$ \\
\hline House furnishing & 5 & $8 \%$ \\
\hline Convenience shop & 4 & $6 \%$ \\
\hline Electric and electronic equipment & 4 & $6 \%$ \\
\hline Clothes retailer & 4 & $6 \%$ \\
\hline Car repair garage & 4 & $6 \%$ \\
\hline $\begin{array}{l}\text { Miscellaneous (2 optical centres, } 1 \\
\text { pet shop, 1 florist and 1 internet } \\
\text { cafe) }\end{array}$ & 5 & $8 \%$ \\
\hline Total & 63 & $100 \%$ \\
\hline
\end{tabular}

Table 1: Type of participating businesses

The size of the business was measured by the number of staff employed and customers served per day. It was established that all the businesses are relatively small in size (i.e. Small to Medium Enterprises, according to Secretariat to National SME Development Council, 2005) with most of them employing less than 10 staff and serving less than 50 customers per day, as illustrated in Table 2. The largest businesses, both in terms of staff employed and customers served, were from the food service sector.

From the background information collected, it was anticipated that businesses from the food service sector produce most of the waste, as they represented the majority of businesses in the area, they employed more staff and they served more customers. This was confirmed by the data collected about waste generation presented in the section below.

\begin{tabular}{|l|l|l|l|}
\hline Number of staff & Percentage & $\begin{array}{l}\text { Number of customers } \\
\text { per day }\end{array}$ & Percentage \\
\hline$<10$ & $80 \%$ & $<50$ & $46 \%$ \\
\hline $20-$ Nov & $18 \%$ & $51-100$ & $21 \%$ \\
\hline$>20$ & $2 \%$ & $>100$ & $33 \%$ \\
\hline
\end{tabular}

Table 2: Size of participating businesses

\section{Waste generation}

A total of 58 respondents reported on their daily waste generation and the results are presented in the form of a frequency histogram. As illustrated in Figure 1, 26 businesses generated less than $25 \mathrm{~kg}$ of waste 
Page 3 of 6

per day, 8 businesses generated between 25 and $50 \mathrm{~kg}$, and 5 businesses between 50 and $75 \mathrm{~kg}$ per day. The average waste generation was $51 \mathrm{~kg}$ per day, although half of the businesses generated less than $25 \mathrm{~kg}$ per day, reflecting the fact that most businesses generate relatively small quantities of waste on a daily basis.

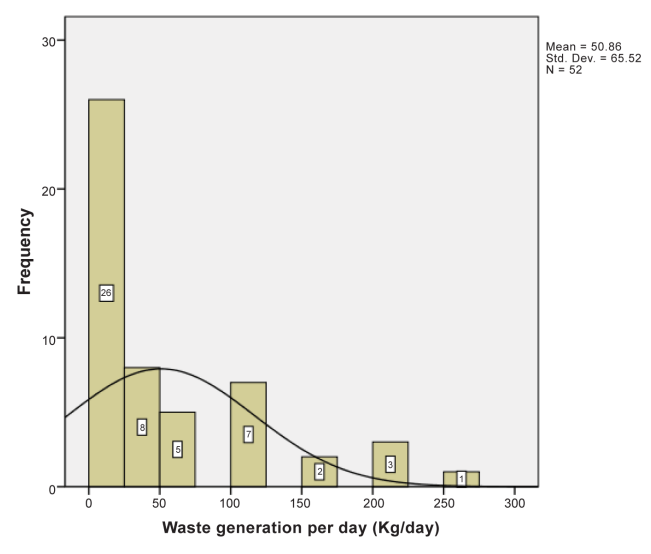

Figure 1: Daily waste generation histogram

Analyzing the waste generation trends in relation to the type of business, revealed the food service group as the largest producer; Table 3 shows that the food service group generated an average of $98 \mathrm{~kg}$ per day. This is followed by the house furnishing businesses with $26.6 \mathrm{~kg}$ per day, car repair garages and convenience shops with $26 \mathrm{~kg}$ per day, health and wellbeing businesses at $25 \mathrm{~kg}$ per day, and finally electric, electronic equipment and clothes retailers that generated on average $16 \mathrm{~kg}$ per day. The statistical analysis of the waste generation for the different business groups, revealed that the mean difference between the groups was statistically significant at $\mathrm{p}<0.05$.

\begin{tabular}{|l|l|l|l|l|l|}
\hline Type of business & N & Minimum & Maximum & Mean & $\begin{array}{l}\text { Std. } \\
\text { Deviation }\end{array}$ \\
\hline Food service & 19 & 1 & 265 & 98.184 & 80.1076 \\
\hline Health and wellbeing & 12 & 0.5 & 106 & 25.083 & 38.5008 \\
\hline House furnishing & 5 & 1 & 106 & 26.6 & 44.6016 \\
\hline Convenience shop & 4 & 0.5 & 100 & 26.125 & 49.2551 \\
\hline $\begin{array}{l}\text { Electric and } \\
\text { electronic equipment }\end{array}$ & 4 & 0.5 & 39 & 16.625 & 19.0848 \\
\hline Car repair garage & 4 & 5 & 53 & 26.375 & 21.8532 \\
\hline Clothes retail & 4 & 1 & 53 & 17.125 & 24.5505 \\
\hline
\end{tabular}

Table 3: Average daily waste generation by business type

The average daily waste generation per customer is presented in Table 4. This table allows comparisons between the different types of businesses. The statistical analysis of the waste generation per costumer for the different business groups, revealed that the mean difference between the groups was statistically significant at $\mathrm{p}<0.05$. The car repair garages had the highest average daily waste generation per customer with $3.3 \mathrm{~kg} /$ customer/day, followed by the food service businesses with $2.2 \mathrm{~kg} /$ customer/day and health and wellbeing with
$1.5 \mathrm{~kg} /$ customer/day. The relatively high daily waste generation per customer by the car repair garages businesses was attributed to the relatively high weight of the waste generated by this type of business. The same applied for food service businesses producing primarily food waste which is relatively heavy due to its high water content and density. Convenience shops and electric and electronic equipment retailers had a lower daily waste generation per customer as explained by the production of relatively lighter wastes such as packaging cardboard and paper.

\begin{tabular}{|l|l|l|l|l|l|}
\hline Type of business & $\mathbf{N}$ & Minimum & Maximum & Mean & $\begin{array}{l}\text { Std. } \\
\text { Deviation }\end{array}$ \\
\hline Car repair garage & 2 & 0.02 & 6.63 & 3.325 & 4.67398 \\
\hline Food service and & 17 & 0.18 & 21.2 & 2.2129 & 5.03502 \\
\hline $\begin{array}{l}\text { Health and } \\
\text { wellbeing }\end{array}$ & 3 & 0.01 & 0.65 & 0.2733 & 0.33471 \\
\hline $\begin{array}{l}\text { Electric } \\
\text { electronic } \\
\text { equipment }\end{array}$ & 2 & 0 & 0.33 & 0.165 & 0.23335 \\
\hline Convenience shop & 4 & 0.05 & 0.42 & 0.155 & 0.17711 \\
\hline House furnishing & 4 & & & & \\
\hline
\end{tabular}

Table 4: Average daily waste generation per customer

Businesses were asked to describe the type of waste they produce in terms of composition. Paper (including newspapers and cardboard) and plastic waste (including plastic packaging, plastic bottles and Styrofoam containers) were the most commonly produced wastes, followed by food waste, aluminum, glass and medical waste. Having food waste as the third most common waste produced was attributed to the high percentage of food outlets amongst the participating businesses.

Comparing the results from this study with other published data revealed several points of discussion. Firstly, the term commercial waste covers a wide range of commercial businesses and in some cases includes wastes from industrial processes. The diverse nature of commercial waste producers led to a wide range of waste generation rates, making it difficult to draw conclusions for the whole waste stream. In addition, possibly due to the difficulties in defining commercial waste, only limited data is available on waste generation and composition. Though this does not allow for extensive comparison between the values derived from this study and other sources, it supports the argument that more empirical data is required and highlights the importance of the present study.

Although methodologies, system boundaries, the social and the material context might differ between studies, a preliminary comparison with other sources reporting on commercial waste generation rates from the food service sector was possible (Table 5). The Californian Department of Resources Recycling and Recovery reported an average waste generation of $8 \mathrm{~kg} / \mathrm{employee} /$ day for commercial premises from the food service sector [20]. The average from this study was higher, at $12 \mathrm{~kg} / \mathrm{employee} /$ day.

A study across Massachusetts reported an average food waste generation rate at restaurants of approximately 40 tons/establishment/ year (Massachusetts Department of Environmental Protection 2002), whereas the Sustainable Restaurant Association (SRA) in the UK reported an average of 24 tons/establishment/year (Sustainable 
Page 4 of 6

Restaurant Association 2010). Both figures are lower than the average from this study at 51 tons/establishment/year [21].

The study by the SRA in the UK also reported an average food waste generation per customer of $0.5 \mathrm{~kg} /$ customer/day. In the current study, the average waste generation from restaurants was $2.2 \mathrm{~kg} /$ customer/day. Assuming that 53 per cent of the total waste in restaurants was food waste (California Integrated Waste Management Board) [20], it was derived that $1.1 \mathrm{~kg} /$ customer/day of food waste was generated by the restaurants in this area. This average figure is significantly higher than the one reported in the UK by the SRA.

\begin{tabular}{|l|l|l|l|}
\hline Waste generation & Waste type & Country & $\begin{array}{l}\text { Comparison with this } \\
\text { study }\end{array}$ \\
\hline $8 \mathrm{~kg} / \mathrm{employee} /$ day & total waste & USA & $12 \mathrm{~kg} / \mathrm{employee} / \mathrm{day}$ \\
\hline 40 tons/restaurant/year & food waste & USA & 51 tons/restaurant/year \\
\hline 24 tons/restaurant/year & food waste & UK & 51 tons/restaurant/year \\
\hline $0.5 \mathrm{~kg} /$ customer/day & food waste & UK & $1.1 \mathrm{~kg} /$ customer/day \\
\hline
\end{tabular}

Table 5: Waste generation trends from the food service sector. Sources: (California Integrated Waste Management Board 2006; Sustainable Restaurant Association [20]; Massachusetts Department of Environmental Protection [21])

These findings raise some concerns considering that the USA and the UK report some of the highest waste generation rates from developed countries. Whilst it is problematic to draw satisfactory conclusions as to why food waste generation rates are high in Malaysia, the relatively low cost of food and the heavily subsidized economy, may provide some clues to the wasteful practices in relation to food.

The authors argue that the high food waste generation rates can be attributed to the relatively low cost of food in Malaysia and the consumers' wasteful behaviors observed in this fast growing economy. Although food prices have increased in recent years, Malaysia's abundance of natural resources and fuel subsidies maintain the relatively low food prices, allowing for wasteful practices in relation to food surplus and waste.

\section{Waste collection}

The participants were asked to give details on the type of waste receptacles they use, the frequency and cost of waste collection. Sixty eight per cent of the businesses had their own collection bin, whereas 29 per cent stated that they simply place their waste in plastic bags at the front of their shop or at the back lane because they do not have bins. No participants admitted that they dispose their liquid waste directly into the drains by the road, although this is a common practice amongst the food outlets observed during the survey. Only half of the food service sector businesses stated they have grease traps installed.

The majority of the respondents ( 89 per cent) receive waste collection services, 8 per cent stated they do not receive any waste collection, while 3 per cent did not respond. The respondents who stated they do not receive any waste collection services highlighted the lack of waste storage facilities as the main reason for not receiving waste collection. In addition, twenty per cent of the respondents did not know who is responsible for their waste collection.
When asked how frequently waste is collected, the majority responded daily, 6 per cent stated they did not know, and the rest gave a variation of answers ranging from once every 2 days, to once a week. The variation in responses was attributed to the lack of interest and / or awareness regarding waste management by the waste producers.

The majority of the participants (73 per cent) did not provide an answer when asked how much they pay for waste collection. Following this up further and discussing in a more informal setting, it was revealed that some participants did not know how much they pay, others did not want to disclose this type of information, and some did not pay at all. Similar results were obtained when the researchers inquired regarding the method of payment for the waste collection services received. The majority did not provide an answer, nearly a third admitted they did not know, and only 26 per cent stated they pay through their rent or directly to a private waste collection company.

The study revealed a number of issues related to waste collection, similar to the ones faced by other developing countries especially in Southeast Asia [22,23]. Firstly, there appeared to be a lack of waste receptacles, both for individual businesses and for public use. The lack of waste bins contributed to littering, and other amenity issues. The provision of additional bins ranked as the top recommendation by the business owners, as explained in the following section.

The second key finding related to the low interest and / or awareness regarding waste management and collection by the business owners. This was revealed by the fact that a large number of businesses were unclear as to who is providing the service, how much it costs and how this fee is recovered, or do not pay at all for waste collection. This issue highlighted the need for a more straightforward and systematic waste collection system, with a simplified cost recovery mechanism accompanied by a communication campaign to improve awareness amongst the waste producers.

In terms of food waste, the limited number of grease traps installed and the common practice observed amongst food outlets to dispose liquid wastes, such as oils and fats, directly into the open drains is another issue requiring attention. This practice not only contributes to pollution of surface water bodies but also leads to amenity issues such as odour and pests.

\section{Feedback on the overall waste management service}

Participants were asked to offer their feedback on the overall waste collection and management service provided, by indicating how satisfied or dissatisfied they are on a Likert style scale. As Figure 2 illustrates, most participants indicated they were 'Moderately satisfied' (35), 18 were 'Satisfied', 3 'Very satisfied', 3 'Very dissatisfied' and 2 'Dissatisfied'.

The participants that responded as 'Moderately satisfied', 'Dissatisfied' and 'Very dissatisfied' were then asked to comment on the issues that contribute to their dissatisfaction. The presence of pests, the odour from the drains and litter on the streets were amongst the most commonly cited problems. These problems were also confirmed by the researchers' observations. Infrequent waste collection appeared to effect only four participants and no one quoted the cost of waste collection as the reason for being dissatisfied with the service received. 
Page 5 of 6

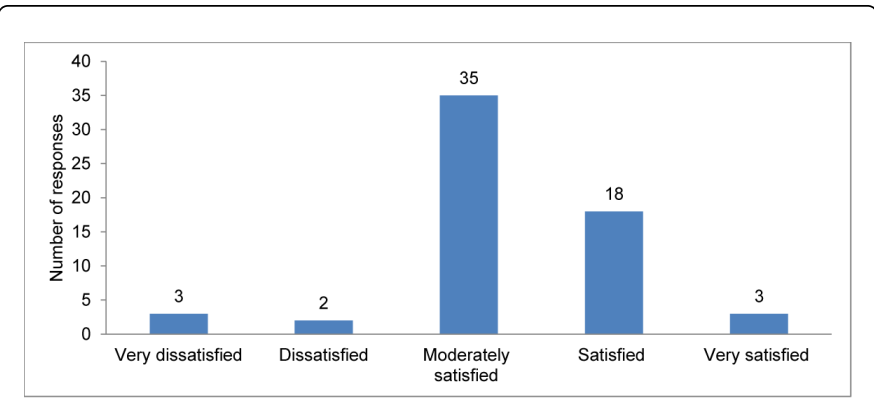

Figure 2: Level of satisfaction with the current waste management system

\begin{tabular}{|l|l|}
\hline Priority & Recommendations \\
\hline 1 & Provide public bins \\
\hline 2 & Improve waste collection services \\
\hline 3 & Improve law enforcement \\
\hline 4 & Increase fines for polluters \\
\hline 5 & Reduce service cost \\
\hline 6 & Carry out regular public awareness campaigns \\
\hline 7 & Offer financial and technical assistance \\
\hline
\end{tabular}

Table 6: Prioritized list of recommendations for improving waste management in the area.

The participants' suggestions for improving waste management in the area are presented in Table 6 in the form of a prioritized list of recommendations. In line with findings from the previous sections of this survey, providing more bins was the highest priority, and improvement of waste collection the second most important recommendation. Better law enforcement and higher financial penalties for polluters were the third and four most important suggestions, whereas reducing cost, carrying out public awareness campaigns and offering financial or technical assistance appeared less important interventions.

Finally, when asked whether they would use recycling bins if they were provided without additional cost, 86 per cent responded in a positive way, whereas 9 per cent gave a negative answer. In addition, the majority of the food and drinks businesses ( 75 per cent) suggested that they would participate in a recycling scheme for used cooked oil, if they could sell it.

The points emerging from this section offer insight on the concerns, expectations and suggestions by the commercial waste producers. The participants' views provided a guide to the existing problems and can inform the direction of future interventions.

In more detail, the feedback indicated a moderately satisfied sample with the waste management service provided. The presence of pests, odorous drains and litter on the streets are the main reasons for dissatisfaction, whereas the waste collection frequency and cost are not. These concerns are related to amenity and public health, rather than commercial waste management per se. However, they can be attributed to the disposal of liquid wastes, such as oils and fats from food outlets, directly into drains. This practice significantly contributed to the problem of pests and odour. Resolving the uncontrolled disposal of liquid wastes would improve these amenity issues, as would the reduction in littering.

The issue of insufficient waste receptacles (both individual for each shop and for public use) was highlighted again in this section, and provision of more bins was suggested as the top priority recommendation for improvement. Finally, businesses in the study area suggested that they would participate in recycling, as well as a used oil collection scheme, if such options were available. The positive response to recycling indicated the waste producers are ready and indeed willing to recycle.

\section{Limitations}

The collected sample (63) represented approximately 23 per cent of the total surveyed population (285) of the study area. Replicating the survey in other commercial districts across Malaysia would further validate the results of this study. As employed by other waste generation studies (Massachusetts Department of Environmental Protection [21]; California Integrated Waste Management Board 2006; Sustainable Restaurant Association [20]) this research relied on waste producers to report on their waste generation rates. Therefore the margin of error related to the waste generation rates is unknown.

\section{Conclusions}

This paper presented a study of commercial and food waste in Malaysia. The study highlighted a number of issues related to the management of commercial waste, such as amenity and public health problems (pests, odour and littering) caused primarily by irresponsible disposal practices of food and liquid wastes, low awareness and interest in waste management, and inefficient provision of waste receptacles. In addition, the food service sector emerged as the main waste producer with food waste generation rates exceeding the ones reported from the UK and the US. These characteristics are typical of developing countries and not unique only to Malaysia [24-27]. However, these same amenity and public health problems can indeed act as drivers for change to a more advanced waste management system. The financial capital to support this transition and maintain the new waste management system can be provided by a simpler and more efficient cost recovery mechanism.

This research has wider implications to waste management policy. It is argued that commercial and food waste has the potential to act as drivers for sustainable resource and waste management. The study suggests that commercial waste in a middle income developing country such as Malaysia provides opportunities for resource efficiency and minimisation through recycling. The willingness of the waste producers to participate in recycling can act as the foundation of business and industry driven changes in waste management. Before capitalizing on this opportunity, problems related to amenity and public health can be resolved by simple infrastructure adjustments such as the provision of bins, grease traps and improved public areas cleansing.

In terms of food waste, the high generation rates reported by this study suggest that food waste should be a priority waste stream in waste management policy prevention and minimisation, in the case of Malaysia. This point is potentially relevant to other countries with similar developmental status as Malaysia, where food waste forms a significant portion of the overall waste stream and is the main 
Citation: Papargyropoulou E, Padfield R, Rupani PF, Zakaria Z (2014) Towards Sustainable Resource and Waste Management in Developing Countries: The Role of Commercial and Food Waste in Malaysia. Int J Waste Resources 4: 151. doi:10.4172/2252-5211.1000151

Page 6 of 6

contributor to public health and amenity problems. Food waste offers an opportunity to formulate waste management strategies appropriate to the specific needs of Malaysia, rather than just adopt ones produced by developed countries for the needs of developed countries.

\section{Acknowledgements}

The researchers would like to express their gratitude to all the research support staff that contributed during the data collection and analysis process; without which this study would not have materialized.

\section{Funding}

This work was supported by the Research Management Centre of the University Technology Malaysia (UTM) [research grant V21000].

\section{References}

1. Population Reference Bureau (2011) The world at seven billion world population data sheet.

2. Renner M (2012) Making the Green Economy Work for Everybody. State of the World 2012.

3. Ogawa H (2000) Sustainable solid waste management in developing countries. 7th ISWA International Congress and Exhibition. Kuala Lumpur Malaysia. World health Organization.

4. Iman A, Chak C, Alan C (2011) Commercial solid waste management for New York City. New York.

5. Salhofer S, Isaac NA (2002) Importance of public relations in recycling strategies: principles and case studies. Environ Manage 30: 68-76.

6. Purcell M, Magette W (2009) Prediction of household and commercial BMW generation according to socio-economic and other factors for the Dublin region. Waste management 29: 1237-1250.

7. WRAP (2011) Co-collection of household and commercial waste and recyclables. Banbury.

8. Papargyropoulou E, Padfield R, Harrison O, Preece C (2012) The rise of sustainability services for the built environment in Malaysia. Sustainable Cities and Society 5: 44-51.

9. Helftewes M, Flamme S, Nelles M (2012) Greenhouse gas emissions of different waste treatment options for sector-specific commercial and industrial waste in Germany. Waste Manag Res 30: 421-431.

10. Yi S, Yoo KY, Hanaki K (2011) Characteristics of MSW and heat energy recovery between residential and commercial areas in Seoul. Waste Manag 31: 595-602.

11. Manaf LA, Samah MA, Zukki NI (2009) Municipal solid waste management in Malaysia: practices and challenges. Waste Manag 29: 2902-2906.
12. Hezri A, Nordin Hasan M (2006) Towards sustainable development? The evolution of environmental policy in Malaysia. Natural Resources Forum 30: 37-50.

13. Agamuthu P, Fauziah HS, Khidzir K (2009) Evolution of solid waste management in Malaysia: impacts and implications of the solid waste bill 2007. Journal of material cycles and waste management 11: 96-103.

14. Isa MH, Asaari FA, Ramli NA, Ahmad S, Siew TS (2005) Solid waste collection and recycling in Nibong Tebal, Penang, Malaysia: a case study. Waste Manag Res 23: 565-570.

15. Kathirvale S, Muhd Yunus MN, Sopian K (2003) Energy potential from municipal solid waste in Malaysia. Renewable Energy 29: 559-567.

16. EPU (2007) Ninth Malaysia Plan 2006 - 2010.

17. Fauziah S, Agamuthu P (2009) Recycling of household organic waste in Malaysia: The challenges Proc of the International Symposium of Environmental Science and Technology. China: Shanghai Science Press USA: 2234-2240.

18. Padfield R, Papargyropoulou E, Preece C (2012) A preliminary assessment of greenhouse gas emission trends in the production and consumption of food in Malaysia. International Journal of Technology 3: 56-66.

19. Murad MW, Siwar C (2007) Waste management and recycling practices of the urban poor: a case study in Kuala lumpur city, Malaysia. Waste Manag Res 25: 3-13.

20. California Integrated Waste Management Board (2006) Targeted Statewide Waste Characterization Study: Waste Disposal and Diversion Findings for Selected Industry Groups. California.

21. Massachusetts Department of Environmental Protection (2002) Identification Characterization and Mapping of Food Waste and Food Waste Generators in Massachusetts. Massachusetts.

22. Seng B, Kaneko H, Hirayama K, Katayama-Hirayama K (2011) Municipal solid waste management in Phnom Penh, capital city of Cambodia. Waste management \& research 29: 491-500.

23. Heisler T (2004) Lessons from Experience: A Comparative Look at Solid Waste Management Policies In Cambodia India The Philippines and Sri Lanka.

24. Guerrero LA, Maas G, Hogland W (2013) Solid waste management challenges for cities in developing countries. Waste Manag 33: 220-232.

25. Asase M, Yanful EK, Mensah M, Stanford J, Amponsah S (2009) Comparison of Municipal Solid Waste Management Systems in Canada and Ghana: a Case Study of the Cities of London Ontario and Kumasi Ghana. Waste management 29: 2779-2786.

26. Henry RK, Yongsheng Z, Jun D (2006) Municipal solid waste management challenges in developing countries--Kenyan case study. Waste Manag 26: 92-100.

27. Mrayyan B, Hamdi MR (2006) Management approaches to integrated solid waste in industrialized zones in Jordan: a case of Zarqa City. Waste Manag 26: 195-205. 